\title{
Uterine blood flow and uterine arterial, venous and luminal concentrations of oestrogens on Days 11, 13 and 15 after oestrus in pregnant and non-pregnant sows
}

\author{
S. P. Ford*, R. K. Christenson and J. J. Ford \\ Roman L. Hruska U.S. Meat Animal Research Center, Clay Center, Nebraska 68933, U.S.A.
}

\begin{abstract}
Summary. Concentrations of oestradiol-17 $\beta$ and oestrone were measured in the uterine arterial and venous blood of anaesthetized sows on Days 11, 13 or 15 of the oestrous cycle or of pregnancy. Uterine arterial blood flow and the amounts of oestradiol-17 $\beta$ and oestrone in uterine flushings were determined in the same animals. In pregnant animals arterial and venous concentrations were significantly different $(P<0.05)$ for oestradiol-17 $\beta$ on Days 11 and 13 and for oestrone on Day 15. Uterine content of both steroids was consistently greater in pregnant than in non-pregnant animals with a peak on Day 13. Uterine arterial blood flow increased from Day 11 to 13 of pregnancy then declined $(P<0.08)$ by Day 15; no change in uterine blood flow occurred on the corresponding days of the oestrous cycle.
\end{abstract}

\section{Introduction}

Maternal recognition of pregnancy in the sow may involve embryonic production of oestrogen with a resultant rise in uterine blood flow. The embryonic signal which initiates luteal maintenance occurs on about Day 12 after mating in the sow (Dhindsa \& Dziuk, 1968) and is associated temporally with a transient increase in blood flow to the gravid uterine horns (Ford \& Christenson, 1979). The pig embryo develops the capacity to synthesize oestrogens in vitro by Day 12 of gestation (Perry, Heap, Burton \& Gadsby, 1976). Oestrogens are known to exert a profound effect on uterine haemodynamics, with increases in blood flow to the porcine uterus being observed following oestrogen administration (Dickson, Bosc \& Locatelli, 1969). Prostaglandin (PG) F-2 $\alpha$ causes premature luteal regression in hysterectomized (Moeljono, Bazer \& Thatcher, 1976) and intact non-pregnant (Connor, Phillips \& Palmer, 1976) gilts with corpora lutea (CL) more than 12 days of age. In addition, elevated levels of PGF- $2 \alpha$ in utero-ovarian venous blood are temporally associated with declining plasma progesterone concentrations during the oestrous cycle (Gleeson, Thorburn \& Cox, 1974). However, concentrations of PGF- $2 \alpha$ in utero-ovarian venous blood of pregnant gilts are significantly reduced on Days 13-17 after mating when compared to those in non-pregnant gilts on similar days after oestrus (Moeljono et al., 1977). Oestrogens of embryonic origin appear to act locally and directly to increase uterine blood flow in pigs, coincident with decreasing concentrations of PGF-2 $\alpha$ in utero-ovarian blood and may, therefore, function to dilute its luteolytic activity.

The present study was conducted to correlate uterine arterial blood flow with uterine content and secretion of oestrone and oestradiol- $17 \beta$ of sows on Days 11,13 and 15 of the oestrous cycle or gestation and to examine their role in maternal recognition of pregnancy. U.S.A.

* Present address: Department of Animal Science, 11 Kildee Hall, Iowa State University, Ames, Iowa 50011, 


\section{Materials and Methods}

Thirty-three non-pregnant sows (Yorkshire, Landrace and Large White) were assigned to this study. On the first day of oestrus (Day 0 ), 18 sows were mated to a mature boar and the remaining 15 were utilized as unmated controls. Mated and unmated sows were assigned, in equal numbers, to surgery on Days 11,13 or 15 .

Food and water were removed from sows $24 \mathrm{~h}$ before surgery. General anaesthesia was induced by intravenous infusion of $1 \mathrm{~g}$ thiopentone sodium (Dipentol: Diamond Labs, Des Moines, Iowa) regardless of body weight. Surgical anaesthesia was maintained with mixtures of oxygen and halothane (Fluothane: Ayerst Labs, New York) administered in a closed-circuit with soda lime for removal of $\mathrm{CO}_{2}$. The uterus was exposed through a midventral incision and a large branch of an artery and vein supplying and draining each uterine horn was cannulated with polyvinyl tubing. In addition, calibrated electromagnetic blood flow transducers were surgically implanted around both middle uterine arteries as described previously (Ford \& Christenson, 1979) and blood flow to both uterine horns was recorded simultaneously and continuously for 20-30 min. During the period of continuous blood flow measurement, $25 \mathrm{ml}$ blood were withdrawn simultaneously from each of the two arterial and two venous catheters at $1-2 \mathrm{ml} / \mathrm{min}$ for determination of serum oestrone and oestradiol- $17 \beta$ concentrations. Blood flow through the middle uterine artery remained unchanged during the period of blood collection. After collection of blood samples the flow transducer was removed from each artery, and each uterine horn was isolated with a tissue clamp at its junction with the uterine body and flushed with $20 \mathrm{ml}$ phosphate-buffered saline $(9 \mathrm{~g} \mathrm{NaCl} / 1, \mathrm{pH} \mathrm{7.3)}$ to obtain embryos (pregnant sows) and/or uterine flushings. Embryonic tissue was recovered from 17 of the 18 mated sows. Embryos were not separated from uterine flushings because of the fragile nature of the embryonic tissue. Instead, conceptuses were dispersed into fragments of embryonic tissue by repeatedly filling a syringe and forcing the uterine flushings through a 20-gauge hypodermic needle. All samples and blood flow recordings obtained from the sow from which no embryonic tissue was recovered (Day-15 mated) were discarded.

$\left[2,4,6,7-{ }^{3} \mathrm{H}(\mathrm{N})\right]$ Oestrone (sp. act. $\sim 115 \mathrm{Ci} / \mathrm{mmol}$ ) and $\left[2,4,6,7-{ }^{3} \mathrm{H}\right.$ (N)oestradiol $17 \beta$ (sp. act. $\sim 96 \mathrm{Ci} / \mathrm{mmol}$ ) were obtained from New England Nuclear (Boston, Massachusetts) and $\sim 1000$ d.p.m. of each were added to $5 \mathrm{ml}$ serum or uterine flushings to correct for procedural losses. After $30 \mathrm{~min}$ samples were extracted twice with $5 \mathrm{ml}$ benzene:hexane $(2: 1 \mathrm{v} / \mathrm{v})$. Extracts were dried under nitrogen gas flow, and oestrone and oestradiol-17 $\beta$ were separated from each other on columns ( $7 \mathrm{~mm}$ i.d.) of Sephadex LH-20 (1 g) as described by Carr, Mikhail \& Flickinger (1971). Columns were eluted with benzene:methanol $(90: 10 \mathrm{v} / \mathrm{v})$, and four sequential fractions were collected: $3 \mathrm{ml}=$ discard, $2.5 \mathrm{ml}=$ oestrone, $1 \mathrm{ml}=$ discard, and $5 \mathrm{ml}=$ oestradiol-17 $\beta$. Eluates were dried under nitrogen gas flow, reconstituted in phosphate-buffered saline ( $\mathrm{pH} 7 \cdot 5$, $0.2 \%$ gelatin), and an aliquot of each was taken to determine percentage recovery which was 85 and $70 \%$ for oestrone and oestradiol- $17 \beta$, respectively.

The oestrogens were measured by a radioimmunoassay which utilized an ovine antiserum (S-310 No. 5, purchased from G. Abraham, Torrance, California). This antiserum was prepared against oestriol-3-trisuccinate-serum albumin and cross-reacted equally with oestrone and oestradiol- $17 \beta(100 \%)$ and only slightly less with oestriol $(78 \%)$ as specified by Tulchinsky \& Abraham (1971). The assay system of Tulchinsky \& Abraham (1971) was used except that the concentration of gelatin in the assay buffer was $0.2 \%$ and the assay was incubated overnight at $4^{\circ} \mathrm{C}$ before addition of dextran-coated charcoal. The precision and accuracy of this procedure were evaluated in triplicate by adding $12 \cdot 5,25,50,100$ and $200 \mathrm{pg}$ oestrone or oestradiol-17 $\beta$ to $5 \mathrm{ml}$ serum from an ovariectomized pig. These standard sera were assayed, and the oestrone or oestradiol- $17 \beta$ concentration of the blank was subtracted. The resulting oestrone concentrations ( \pm s.e.m.) were $13.6 \pm 0.7,27.5 \pm 1.6,48.0 \pm 1.8,101.3 \pm 6.7$ and $210.8 \pm 5.2 \mathrm{pg}$ and the oestradiol-17 $\beta$ concentrations $( \pm$ s.e.m.) were $14 \cdot 3 \pm 1 \cdot 1,26 \cdot 7 \pm 2 \cdot 5,48 \cdot 5 \pm 4 \cdot 9,107.2 \pm$ 
2.8 and $216 \pm 5.0 \mathrm{pg}$. For a pool of serum that was included in every assay and contained $13 \mathrm{pg}$ oestrone $/ \mathrm{ml}$ and $25 \mathrm{pg}$ oestradiol $-17 \beta / \mathrm{ml}$, interassay coefficients of variation were $12 \%$ for oestrone, and $18 \%$ for oestradiol- $17 \beta$.

Beginning the day after surgery, sows were checked daily for oestrous activity with a mature boar. Post-operative difficulties occurred with two Day-11 and one Day-13 non-pregnant sows and one Day-11 pregnant sow; thus data from these animals were not obtained.

Blood flow $(\mathrm{ml} / \mathrm{min})$ was averaged for each artery over the $20-30-\mathrm{min}$ monitoring period and this average was considered as a single observation for statistical analyses. Uterine arterial blood flow responses and changes in serum concentrations of ovarian steroids were analysed by factorial analysis of variance techniques (Kirk, 1968). Means were compared by linear contrasts.

\section{Results}

There were no differences in the concentrations of the two oestrogens in the uterine arterial and uterine venous blood of non-pregnant sows on Days 11,13 or 15 of the oestrous cycle (Table 1). In pregnant sows, however, concentrations of oestradiol-17 $\beta$ were greater $(P<0.05)$ in uterine venous blood than in uterine arterial blood on Days 11 and 13 of gestation (Table 1). This arterial-venous difference in oestradiol-17 $\beta$ had disappeared by Day 15 of gestation because of the decreased concentrations in the uterine vein. In contrast, there were no arterial-venous differences in oestrone until Day 15 of gestation when concentrations in the uterine vein exceeded $(P<0.05)$ those in the uterine artery.

Table 1. Serum concentrations of oestrogens in the uterine artery and uterine vein of nonpregnant and pregnant sows

\begin{tabular}{|c|c|c|c|c|c|}
\hline \multirow[b]{2}{*}{$\begin{array}{l}\text { Day of oestrous } \\
\text { cycle/pregnancy }\end{array}$} & \multirow[b]{2}{*}{$\begin{array}{l}\text { No. of } \\
\text { sows }\end{array}$} & \multicolumn{2}{|c|}{ Oestradiol-17 $\beta$} & \multicolumn{2}{|c|}{ Oestrone } \\
\hline & & $\begin{array}{l}\text { Uterine artery } \\
\qquad(\mathrm{pg} / \mathrm{ml})\end{array}$ & $\begin{array}{l}\text { Uterine vein } \\
(\mathrm{pg} / \mathrm{ml})\end{array}$ & $\begin{array}{l}\text { Uterine artery } \\
\qquad(\mathrm{pg} / \mathrm{ml})\end{array}$ & $\begin{array}{l}\text { Uterine vein } \\
\qquad(\mathrm{pg} / \mathrm{ml})\end{array}$ \\
\hline \multicolumn{6}{|l|}{ Non-pregnant sows } \\
\hline 11 & 5 & $3.9 \pm 1.0$ & $4.0 \pm 0.6$ & $12.2 \pm 0.8$ & $12 \cdot 2 \pm 1.8$ \\
\hline 13 & 5 & $4 \cdot 7 \pm 1 \cdot 1$ & $4 \cdot 3 \pm 1 \cdot 3$ & $13 \cdot 3 \pm 2 \cdot 1$ & $12 \cdot 1 \pm 2 \cdot 0$ \\
\hline 15 & 5 & $8 \cdot 2 \pm 1 \cdot 1$ & $8.9 \pm 1.6$ & $15 \cdot 8 \pm 1 \cdot 6$ & $16 \cdot 5 \pm 2 \cdot 3$ \\
\hline \multicolumn{6}{|l|}{ Pregnant sows } \\
\hline 11 & 6 & $3.9 \pm 0.5$ & $7 \cdot 2 \pm 2 \cdot 0^{*}$ & $11 \cdot 1 \pm 1 \cdot 1$ & $13 \cdot 2 \pm 1 \cdot 4$ \\
\hline 13 & 6 & $4 \cdot 4 \pm 1 \cdot 1$ & $7.6 \pm 1.4^{*}$ & $15 \cdot 6 \pm 2 \cdot 7$ & $17 \cdot 1 \pm 2 \cdot 7$ \\
\hline 15 & 5 & $3.6 \pm 1 \cdot 1$ & $4.1 \pm 0.8$ & $9.7 \pm 0.6$ & $13.8 \pm 0.6^{*}$ \\
\hline
\end{tabular}

Values are mean \pm s.e.m.

* Significantly different from arterial value on same day $(P<0.05)$.

Only sows with blastocysts greater than $8 \mathrm{~mm}$ in diameter on Day 11 of gestation had elevated concentrations of oestrogens in uterine flushings when compared to flushings from Day 11 unmated controls (Table 2). On Days 13 and 15, uterine flushings from all pregnant sows contained markedly elevated $(P<0.001)$ levels of oestrone and oestradiol-17 $\beta$ compared with flushings from non-pregnant sows (Table 2). Among pregnant sows, uterine flushings on Day 13 had a greater $(P<0.05)$ content of oestrone, as well as of oestradiol-17 $\beta$, than did those on Day 15 of gestation.

Blood flow through the right and left middle uterine arteries of each sow, which supply $60-90 \%$ of the blood flow to their respective horns, did not differ significantly and data for the right and left uterine arterial blood flow were therefore pooled (Table 3). Due to technical difficulties, uterine arterial blood flow could not be obtained for one Day-13-pregnant sow. 
Table 2. Total amount of oestradiol-17 $\beta$ and oestrone in flushings from uterine horns of pregnant* and non-pregnant sows

\begin{tabular}{|c|c|c|c|c|}
\hline $\begin{array}{l}\text { Day after } \\
\text { oestrus or mating }\end{array}$ & $\begin{array}{l}\text { Reproductive } \\
\text { state }\end{array}$ & $\begin{array}{l}\text { No. of } \\
\text { uterine } \\
\text { horns }\end{array}$ & $\begin{array}{l}\text { Oestradiol-17 } \beta \\
(\mathrm{pg})\end{array}$ & $\begin{array}{l}\text { Oestrone } \\
(\mathrm{pg})\end{array}$ \\
\hline \multirow[t]{2}{*}{11} & $\begin{array}{l}\text { Non-pregnant } \\
\text { Pregnant }\end{array}$ & 10 & $20 \pm 3^{a}$ & $85 \pm 21^{a}$ \\
\hline & $\begin{array}{l}\text { Blastocysts 2-5 mm diam. } \\
\text { (Blastocysts } 8-10 \mathrm{~mm} \text { diam. }\end{array}$ & $\begin{array}{l}8 \\
4\end{array}$ & $\begin{aligned} 86 & \pm 58^{\mathrm{a}} \\
3418 & \pm 86\end{aligned}$ & $\begin{array}{r}81 \pm 18^{a} \\
1132 \pm 50) \dagger\end{array}$ \\
\hline \multirow[t]{2}{*}{$13^{\circ}$} & Non-pregnant & 10 & $54 \pm 28^{\mathrm{a}}$ & $60 \pm 11^{\mathrm{a}}$ \\
\hline & Pregnant & 12 & $7204 \pm 3753^{b}$ & $2029 \pm 646^{\mathrm{b}}$ \\
\hline \multirow[t]{2}{*}{15} & Non-pregnant & 10 & $51 \pm 12^{\mathrm{a}}$ & $131 \pm 27^{a}$ \\
\hline & Pregnant & 10 & $1327 \pm 488^{c}$ & $819 \pm 290^{c}$ \\
\hline
\end{tabular}

* Embryonic tissue was not removed from uterine flushings.

$\dagger$ Excluded from the analysis due to insufficient numbers of sows.

Values are mean \pm s.e.m.; within each column, values with different superscripts are significantly different, $P<0.05$.

Uterine arterial blood flow of non-pregnant sows did not differ on Days 11, 13 or 15 and averaged $81.2 \pm 8.4 \mathrm{ml} / \mathrm{min}$ (Table 3). Day-13-pregnant sows exhibited increased $(P<0.05)$ uterine blood flow $(203.6 \pm 22.9 \mathrm{ml} / \mathrm{min})$ when compared to that of the unmated sows on this day and of mated sows on Day $11(86.6 \pm 12.9 \mathrm{ml} / \mathrm{min})$. On Day 15 of pregnancy blood flow values were lower than those on Day 13 of pregnancy $(P<0.08)$ and similar to those of unmated animals on Day 15.

Table 3. Uterine arterial blood flows and oestrous cycle lengths of non-pregnant and pregnant sows

\begin{tabular}{|c|c|c|c|c|}
\hline \multirow[b]{2}{*}{ Day } & \multicolumn{2}{|c|}{$\begin{array}{l}\text { Uterine arterial blood flow } \\
\text { (ml/min) }\end{array}$} & \multicolumn{2}{|c|}{$\begin{array}{l}\text { Oestrous cycle } \\
\text { (days) }\end{array}$} \\
\hline & Non-pregnant & Pregnant & Non-pregnant & Pregnant \\
\hline $\begin{array}{l}11 \\
13 \\
15\end{array}$ & $\begin{array}{l}95 \cdot 2 \pm 17 \cdot 3 \\
82 \cdot 7 \pm 13 \cdot 3 \\
65 \cdot 9 \pm 12 \cdot 6\end{array}$ & $\begin{array}{c}86.6 \pm 12.9 \\
203.6 \pm 22.9^{*} \\
128.8 \pm 35.3\end{array}$ & $\begin{array}{l}21 \cdot 7 \pm 0.9 \\
21 \cdot 0 \pm 0.7 \\
21.8 \pm 0.6\end{array}$ & $\begin{array}{l}22.0 \pm 1.1 \\
25.8 \pm 0.6^{*} \\
26.4 \pm 0.9^{*}\end{array}$ \\
\hline
\end{tabular}

Values are mean \pm s.e.m.

* Significantly different from non-pregnant value on same day $(P<0.05)$.

Oestrous cycle lengths are shown in Table 3. The mean value for the non-pregnant sows was $21.5 \pm 0.4$ days, while that for pregnant sows with uteri flushed on Days 13 and 15 was $26.1 \pm$ 0.5 days.

\section{Discussion}

Previous results (Ford \& Christenson, 1979) have demonstrated a local influence of the conceptus in increasing blood flow to gravid uterine horns of sows on Days 12 and 13 of gestation which have been shown to be the critical days for pregnancy recognition in this species (Dhindsa \& Dziuk, 1968). This association between increased uterine blood flow and pregnancy recognition was confirmed in the present study which demonstrated a significant increase in uterine arterial blood flow on Day 13 of gestation, the first day on which flushing of embryos from the uteri lengthened the interval to next oestrus. These data also demonstrate that increased concentrations of oestrone and oestradiol-17 $\beta$ in uterine flushings from pregnant sows are 
associated temporally with the observed increase in uterine blood flow on Day 13 of gestation. By Day 15 of gestation, uterine blood flow and elevated concentrations of oestrogens in the uterine lumen had declined significantly when compared with values on Day 13, further suggesting an association between the levels of uterine oestrogens and the transient increase in uterine blood flow.

Concentrations of oestradiol-17 $\beta$ but not oestrone were greater in uterine venous blood than uterine arterial blood on Days 11 and 13 of pregnancy and reflect the higher content of oestradiol- $17 \beta$ than oestrone found in uterine flushings from pregnant sows in this study. These data are in agreement with those of Moeljono et al. (1977) who reported that oestradiol-17 $\beta$ concentrations were uniformly higher in uterine venous blood of pregnant gilts when compared to non-pregnant controls on Days 12-17 after mating or oestrus, while oestrone increases were of lower magnitude. By Day 15 of gestation, the arterio-venous difference in oestradiol-17 $\beta$ values across the uterus had disappeared coincident with a drop in intraluminal oestradiol concentration. Concentrations of oestrone in uterine arterial blood appeared to drop more than those in the uterine vein from Day 13 to 15 of gestation, resulting in a significant arterio-venous difference.

According to Perry et al. (1976) the pig blastocyst develops the capacity to synthesize oestrogen by Day 12 and the data presented here and elsewhere (Robertson \& King, 1974; Moeljono et al., 1977) demonstrate elevated plasma oestrogen concentrations by Day 12 through 16 of gestation in sows. These steroids appear to be derived from the conceptus, as suggested by the high concentrations of both oestrone and oestradiol-17 $\beta$ in porcine conceptus tissue on Days 12 and 13 of gestation (Gadsby \& Heap, 1978). Gadsby \& Heap (1978) also demonstrated a significant decline in conceptus oestrogen concentrations from Days 13 to 15 of gestation which is in close agreement with the present data. Consequently, oestrogen has been proposed as the possible luteotrophic agent in sows. This concept is strengthened by the fact that oestrogens are luteotrophic when administered systemically (Gardner, First \& Casida, 1963) or into the uterine lumen (Ford \& Magness, 1980) between Days 11 and 15 after the onset of oestrus in sows.

The role of the transient rise in uterine arterial blood flow on Days 12 and 13 of pregnancy in maternal recognition of pregnancy may result from its dilution of the luteolysin, PGF- $2 \alpha$, in uterine venous blood thus preventing luteolysis. Shille et al. (1979) demonstrated significantly greater concentrations of 15-keto-13,14-dihydro-prostaglandin F2 $\alpha$ in systemic blood of pregnant gilts when compared to non-pregnant gilts on Days 11 to 13 of gestation or the oestrous cycle, respectively, at a time when concentrations of PGF- $2 \alpha$ in uterine venous blood are lower in pregnant than non-pregnant animals (Moeljono et al., 1977). It has been demonstrated that 15-keto-13,14-dihydroprostaglandin F-2 $\alpha$ is the major blood plasma metabolite of PGF- $2 \alpha$ in systemic blood (Kindahl, Edqvist, Granström \& Bane, 1976) and it has been suggested that measurement of the metabolite may be the best means of following PGF- $2 \alpha$ release in vivo. If this premise is true, a greater amount of PGF-2 $\alpha$ is being secreted by uteri of pregnant than non-pregnant gilts on days critical for pregnancy recognition in this species. The reduced concentrations of PGF- $2 \alpha$ in uterine venous blood during this period of early pregnancy may result from dilution of PGF- $2 \alpha$ by the increased quantitities of uterine venous blood associated with the transient rise in uterine blood flow. These data do not, however, preclude an additional direct luteotrophic effect of uterine oestrogens on luteal function for which we have some evidence (Ford \& Magness, 1980).

The reason for the apparent decrease in uterine blood flow and uterine oestrogen concentrations observed on Day 15 in this study is not known but may be related to the conceptus entering a more advanced stage of development. On Days 9 and 10 of pregnancy, pig blastocysts are spherical or ovoid and rapidly elongate on Days 11 and 12 to attain lengths of $>60 \mathrm{~cm}$ by Day 13 (Anderson, 1978). In the present study, only Day-11 embryos which had begun to increase in diameter were associated with increased levels of oestrogens in uterine 
luminal fluid, suggesting an association between conceptus growth and oestrogen secretion. The process of rapid conceptus elongation is completed by Day 13 of gestation, with implantation beginning as early as Day 13 and well advanced by Day 18 (Perry et al., 1976). The data presented here suggest an association between conceptus elongation, intrauterine oestrogen production and secretion, and increased uterine blood flow in sows at a time critical for pregnancy recognition.

We thank Bill McDonald and George McMillan for their excellent technical assistance and the staff of the Agricultural Experiment Station, University of Nebraska for co-operation.

Mention of a trade name, proprietary product, or specific equipment does not constitute a guarantee or warranty by the U.S. Department of Agriculture and does not imply its approval to the exclusion of other products that may be suitable.

\section{References}

Anderson, L.L. (1978) Growth, protein content and distribution of early pig embryos. Anat. Rec. 190, 143-154.

Carr, B.R., Mikhail, G. \& Flickinger, G.L. (1971) Column chromatography of steroids on sephadex LH-20. J. clin. Endocr. Metab. 33, 358-360.

Connor, L., Phillips, G.D. \& Palmer, W.M. (1976) Effects of prostaglandin $F_{2} \alpha$ on the estrous cycle and hormone levels in the gilt. Can. J. Anim. Sci. 56, 661-669.

Dhindsa, D.S. \& Dziuk, P.J. (1968) Effect on pregnancy in the pig after killing embryos or fetuses in one uterine horn in early gestation. J. Anim. Sci. $27,122-126$.

Dickson, W.M., Bosc, M.J. \& Locatelli, A. (1969) Effect of estrogen and progesterone on uterine blood flow in castrate sows. Am. J. Physiol. 217, 14311434.

Ford, S.P. \& Christenson, R.K. (1979) Blood flow to uteri of sows during the estrous cycle and early pregnancy: local effect of the conceptus on the uterine blood supply. Biol. Reprod. 21, 617-624.

Ford, S.P. \& Magness, R.R. (1980) Effect of intra-uterine infusions of estradiol-17 $1\left(E_{2} \beta\right)$ on luteal function in nonpregnant sows. J. Anim. Sci. 51 (Suppl. 1), 279 Abstr. 421.

Gadsby, J.E. \& Heap, R.B. (1978) Steroid hormones and their synthesis in the early embryo. In Novel Aspects of Reproductive Physiology, pp. 263-285. Eds C. H. Spilman \& J. W. Wilks. SP Medical and Scientific Books, New York.

Gardner, M.L., First, N.L. \& Casida, L.E. (1963) Effect of exogenous estrogen on corpus luteum maintenance in gilts. J. Anim. Sci. 22, 132-134.

Gleeson, A.R., Thorburn, G.A. \& Cox, R.I. (1974) Prostaglandin $\mathrm{F}$ concentration in the utero-ovarian venous plasma of the sow during the late luteal phase of the oestrous cycle. Prostaglandins 5, 521-529.
Kindahl, H., Edqvist, L.E., Granstrüm, E. \& Bane, A. (1976) The release of prostaglandin $F_{2} \alpha$ as reflected by 15-keto-13,14-dihydroprostaglandin $F_{2} \alpha$ in the peripheral circulation during normal luteolysis in heifers. Prostaglandins 11, 871-878.

Kirk, R.E. (1968) Experimental Design: Procedures for the Behavioral Sciences. Wadsworth Publishing Co., Belmont, California.

Moeljono, M.P., Bazer, F.W. \& Thatcher, W.W. (1976) A study of prostaglandin $F_{2} \alpha$ as the luteolysin in swine I. Effect of prostaglandin $F_{2} \alpha$ in hysterectomized gilts. Prostaglandins 11, 737-743.

Moeljono, M.P., Thatcher, W.W., Bazer, F.W., Frank, M., Owens, L.J. \& Wilcox, C.J. (1977) A study of prostaglandin $F_{2}$ as the luteolysin in swine II. Characterization and comparison of prostaglandin $\mathrm{F}$, estrogens and progestin concentrations in uteroovarian vein plasma of nonpregnant and pregnant gilts. Prostaglandins 14, 543-555.

Perry, J.S., Heap, R.B., Burton, R.D. \& Gadsby, J.E. (1976) Endocrinology of the blastocyst and its role in the establishment of pregnancy. J. Reprod. Fert., Suppl. 25, 85-104.

Robertson, H.A. \& King, G.J. (1974) Plasma concentration of progesterone, oestrone, oestradiol$17 \beta$ and oestrone sulphate in the pig at implantation, during pregnancy and at parturition. J. Reprod. Fert. 40, 133-141.

Shille, V.M., Karlbom, I., Einarsson, S., Larsson, K., Kindahl, H. \& Edqvist, L.E. (1979) Concentrations of progesterone and 15-keto-13,14-dihydroprostaglandin $F_{2} a$ in peripheral plasma during the estrous cycle and early pregnancy in gilts. Zentbl. VetMed. 26, 169-181.

Tulchinsky, D. \& Abraham, G.E. (1971) Radioimmunoassay of plasma estriol. J. clin. Endocr. Metab. 33, 775-782. 